\title{
Analisis Rangkaian Full Wave Rectifier dengan Filter Kapasitor, Pembagi Tegangan, Buffer dan Penguat Differensial pada Sensor Arus
}

\author{
Andhika Giyantara ${ }^{1}$, Mudeng, Vicky ${ }^{2}$, Rizky Ramadhani $^{3}$, Rizky Wulandari $^{4}$ \\ ${ }^{1}$ Teknik Elektro, Teknologi Industri dan Proses, Institut Teknologi Kalimantan, Balikpapan. Email: \\ dhika@itk.ac.id \\ ${ }^{2}$ Teknik Elektro, Teknologi Industri dan Proses, Institut Teknologi Kalimantan, Balikpapan. Email: \\ mudengvicky@itk.ac.id \\ ${ }^{3}$ Teknik Elektro, Teknologi Industri dan Proses, Institut Teknologi Kalimantan, Balikpapan. Email: \\ 04161066@itk.ac.id \\ ${ }^{4}$ Teknik Elektro, Teknologi Industri dan Proses, Institut Teknologi Kalimantan, Balikpapan. Email: \\ 04161067@itk.ac.id
}

\begin{abstract}
In this work presents design and analysis of a current sensor with a full wave rectifier, filter capacitor, voltage divider, buffer, and differential amplifier circuits. Current sensing with a resistor in voltage divider circuit as a reference resistor (Rs) to measure the current value used as a method. This method based on Ohm's Law to determine the current value through the measured path. Experimental results verify the proposed theory.
\end{abstract}

Keywords: current sensor circuit, current measurement, resistive method

\begin{abstract}
Abstrak
Penelitian ini menyajikan perancangan dan analisis sebuah sensor arus yang terdiri dari rangkaian penyearah gelombang penuh dengan filter kapasitor, pembagi tegangan, buffer, dan penguat diferensial. Metode yang digunakan untuk mengukur nilai arus pada sensor adalah dengan menetapkan salah satu resistor pada rangkaian pembagi tegangan sebagai resistor referensi (Rs). Metode ini didasarkan pada hukum Ohm dalam menentukan nilai arus yang melalui suatu jalur. Hasil percobaan yang dilakukan telah membuktikan teori yang disajikan.
\end{abstract}

Kata Kunci: metode resistif, pengukuran arus, rangkaian sensor arus.

\section{Pendahuluan}

Sistem pengukuran memiliki peranan penting dalam kehidupan manusia, khususnya untuk mengetahui nilai kuantitas fisik. Pengukuran merupakan perbandingan nilai fisik yang tidak diketahui dengan nilai yang diketahui. Hasil dari pengukuran bersifat umum, yang mana dapat dinyatakan dalam angka dan satuan atau nilai dan satuan, seperti pengukuran kecepatan, berat, suhu dan lainnya. Salah satu komponen pengukuran adalah sensor. Sensor adalah alat yang digunakan untuk mendeteksi atau mengukur suatu nilai kuantitas fisik. Sensor merupakan suatu transduser untuk mengubah satuan mekanik, magnetik, panas, cahaya, dan kimiawi kedalam satuan listrik yaitu tegangan dan arus (Dimitrios, 2017).

Sebuah sensor akan menghasilkan tegangan dan tegangan tersebut yang dijadikan sebagai acuan dalam sensor arus (Peter, 2012). Sensor Arus merupakan sebuah alat yang dapat mendeteksi dan mengkonversi arus agar dapat diukur dengan mudah melalui tegangan keluaran yang mewakili arus terukur pada lintasan yang dilalui. Sensor arus diperlukan untuk dapat membatasi jumlah arus yang mengalir dalam suatu lintasan, selain itu sensor arus dapat mendeteksi kerusakan seperti hubungan arus singkat (Givelin, 1995).

Dalam penelitian ini, rangkaian gelombang penyearah penuh digunakan untuk menyearahkan tegangan AC menjadi DC (Jake, 2014). Ketika tegangan AC dikonversi menjadi tegangan DC menggunakan penyearah, keluaran DC akan mengandung bagian yang tidak diinginkan yang disebut ripple (Pryakurial, 2013). Ripple dapat diredam dengan menggunakan filter. Pada rangkaian sensor ini, kapasitor digunakan untuk menenkan ripple yang terjadi saat proses penyearahan gelombang AC 
(Sirish, 2017). Tegangan keluaran dari filter kapasitor akan masuk kedalam rangkaian pembagi tegangan, yang mana rangkaian ini digunakan untuk merepresentasikan arus yang terukur pada beban sesungguhnya (Theventira, 2016). Tegangan output dari pembagi tegangan diredam sehingga mendapat rentang sinyal yang diinginkan, menggunakan rangkaian pengondisi sinyal yaitu penguat differensial, Penguat differensial adalah penggunaan opamp untuk mencari selisih antara dua buah titik tegangan yang berbeda (Akhmad, 2012).

Dalam mengukur suatu arus dalam rangkaian, terdapat tiga metode dasar yang dapat diimplementasikan berdasarkan aplikasinya yaitu metode resistif, optikal, dan magnetik. Ketiga metode tersebut memilki kelebihan dan kekurangan masing-masing. Faktor yang harus dipertimbangkan dalam memilih metode pengukuran yang akan digunakan dalam sensor arus dapat meliputi rentang arus yang akan diukur, biaya, akurasi, dan waktu tanggap sistem (Bode, 2008).

\section{Metode}

Penelitian mengenai analisis sensor arus dengan metode resistif ini dilakukan untuk membuktikan teori yang telah ada. Analisis ini juga dilakukan untuk membuktikan bahwa sensor arus yang dirancang dapat digunakan untuk sambungan listrik yang terhubung dengan PLN.

Rangkaian sensor yang dirancang pada penelitian ini memiliki bagian utama seperti yang terlihat pada gambar 1.

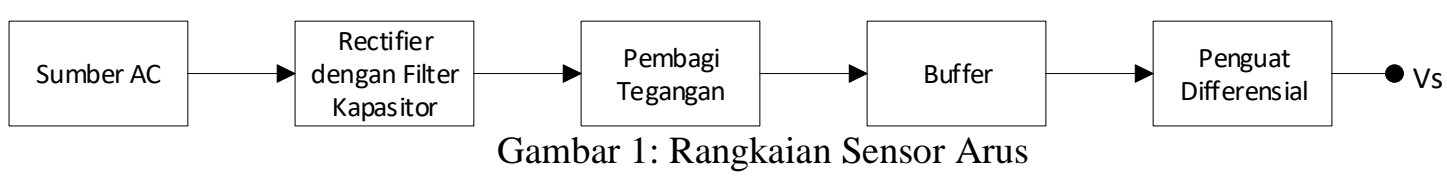

Sumber: Penulis 2018

Terdapat empat bagian utama dalam rangkaian sensor arus yang ditunjukkan pada Gambar 1. Tiap bagian ini memiliki peran penting agar sensor bekerja sesuai yang diharapkan. Sumber tegangan AC dari PLN (220V) akan masuk ke rangkaian Rectifier dengan filter kapasitor untuk diubah menjadi tegangan DC. Tegangan DC dari rangkaian Rectifier dengan filter kapasitor akan melalui rangkaian pembagi tegangan, dimana bagian ini digunakan sebagai tempat pengimplementasian metode pengukuran arus resistif. Setelah itu terdapat rangkaian buffer untuk menjaga keluaran nilai tegangan dari rangkaian pembagi tegangan tetap stabil atau dengan kata lain nilainya tetap sama saat memasuki rangkaian penguat differensial. Pada bagian terakhir terdapat rangkaian penguat differensial. Rangkaian ini dirancang sedemikian rupa agar tegangan keluaran dari sensor memiliki rentang $0-5$ Volt. Rentang tegangan ini dipilih menyesuaikan dengan masukkan tegangan maksimal pada pada pin analog ADC yang terdapat pada mikrokontroler. Hal ini dilakukan agar kedepannya sensor arus ini dapat digunakan oleh berbagai mikrokontroler dalam melakukan pengukuran arus pada suatu rangkaian listrik AC ke DC.

\subsection{Full wave Rectifier dengan Filter Kapasitor}

Rangkaian rectifier dengan filter kapasitor merupakan rangkaian yang digunakan untuk menyearahkan gelombang AC menjadi gelombang DC. Rangkaian ini menggunakan dioda. Terdapat dua jenis rangkaian rectifier yaitu rangkaian half wave rectifier dan full wave rectifier. Half wave rectifier merupakan rangkaian penyearah setengah gelombang yang menghambat sisi sinyal negatif dari gelombang AC dan melewatkan sisi sinyal positifnya. Sedangkan rangkaian rectifier yang digunakan pada penelitian ini adalah full wave rectifier yang merupakan rangkaian penyearah gelombang penuh yang akan menyearahkan kedua sisi gelombang sehingga ripple yang dihasilkan tidak sebesar rangkaian half wave rectifier.

Pada prinsipnya, arus AC terdiri dari dua sisi gelombang yaitu sisi positif dan sisi negatif yang bolakbalik(gelombang sinusoidal). Sisi positif gelombang dari arus AC yang masuk ke dioda akan menyebabkan dioda menjadi bias maju (forward bias) sehingga melewatkannya, sedangkan sisi negative gelombang arus AC yang masuk akan menjadikan dioda dalam keadaan bias mundur (reverse bias) sehingga menghambat sinyal negatif tersebut. Tegangan yang dihasilkan oleh rangkaian rectifier ini belum benar-benar rata, sehingga digunakan kapasitor sebagai filter untuk menekan ripple yang terjadi pada proses penyearahan gelombang AC. 


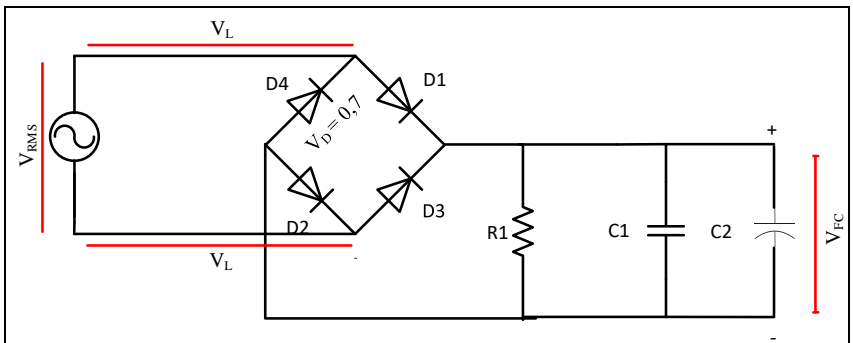

Gambar 2: Rangkaian Full Wave Rectifier dengan Filter Kapasitor

Sumber: Penulis 2018

Tegangan keluaran yang dihasilkan dari rangakaian rectifier dengan filter kapasitor ini dapat dirumuskan sebagai berikut:

$$
\begin{gathered}
V_{F C}=V_{L}-\left(2 \cdot V_{D}\right) \\
V_{L}=V_{r m s} \times \sqrt{2}
\end{gathered}
$$

Dimana :

$V_{F C}$ merupakan tegangan keluaran dari filter kapasitor, $V_{L}$ merupakan tegangan awal setelah diberi beban,

$V_{r m s}$ merupakan tegangan root mean square

$V_{D}$ merupakan tegangan internal dari dioda yaitu 0,7 Volt untuk silikon

\subsection{Pembagi Tegangan}

Rangkaian pembagi tegangan merupakan rangkaian sederhana yang digunakan untuk mengubah nilai tegangan menjadi lebih kecil dari nilai sebelumnya. Rangkaian pembagi tegangan pada penelitian sensor arus ini digunakan untuk menerapkan dan menguji metode resistif yang digunakan pada pengukuran arus .

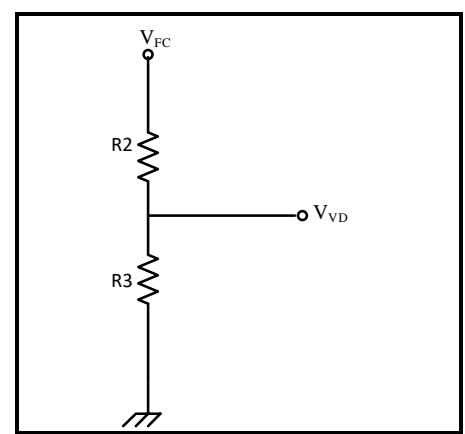

Gambar 3: Rangkaian Pembagi Tegangan Sumber: Penulis 2018

$$
V_{V D}=\frac{R 2}{R 2+R 3} V_{F C}
$$

Dimana :

$V_{V D}$ merupakan tegangan keluaran dari rangkaian pembagi tegangan,

$V_{F C}$ merupakan tegangan masukkan dari rangkaian filter kapasitor,

$R_{2}$ dan $R_{3}$ merupakan tahanan.

\subsection{Buffer}

Rangkaian buffer merupakan rangkaian yang menghasilkan tegangan keluaran yang sama dengan tegangan masukannya. Dalam hal ini sama seperti rangkaian common collector yang memiliki penguatan 1. Dalam penelitian rangkaian sensor arus, rangkaian buffer berfungsi sebagai penyangga, dimana prinsip kerjanya adalah penguat arus tanpa terjadi penguatan tegangan. Sehingga semua arus akan mengalir ke R2 pada rangkaian pembagi tegangan yang nantinya dijadikan sebagai $\mathrm{R}_{\mathrm{S}}$ (resistor 
referensi) pada pengukuran arus metode resistif. Rangakaian buffer dibangun dari rangkaian penguat dasar (operational amplifier) menjadi sangat sederhana karena tidak diperlukan komponen tembahan pada konfigurasi buffer non-inverting.

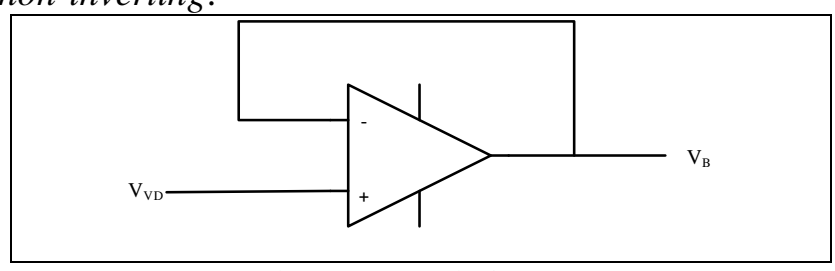

Gambar 4: Rangkaian Buffer

Sumber: Penulis 2018

Jalur masukan $\left(V_{V D}\right)$ inverting dihubungkan dengan jalur keluaran rangkaian operational amplifier, maka rangkaian buffer pada gambar 4 akan memberikan kemampuan mengalirkan arus secara maksimal sesuai kemampuan maksimal operational amplifier mengalirkan arus keluaran. Dengan metode hubung singkat antara jalur masukkan inverting dan jalur keluaran, maka dapat diperoleh persamaan sebagai berikut :

$$
\begin{gathered}
V_{B}=\left(1+\frac{R f}{R i}\right) V_{V D} \\
V_{B}=\left(1+\frac{0}{\infty}\right) V_{V D} \\
V_{B}=(1+0) V_{V D} \\
V_{B}=V_{V D}
\end{gathered}
$$

Dimana :

$R f$ merupakan tahanan feedback, $R i$ merupakan tahanan masukkan, $V_{V D}$ merupakan tegangan masukkan dari rangkaian pembagi tegangan, $V_{B}$ merupakan tegangan keluaran dari rangkaian buffer.

\subsection{Penguat Differensial}

Operational Amplifier adalah rangkaian penguat berpenguatan tinggi yang terintegrasi dalam sebuah IC (integrated circuit) yang memiliki dua buah masukkan inverting dan non-inverting dengan sebuah terminal keluaran, dimana rangkaian umpan balik (feedback) dapat ditambahakan untuk mengendalikan karakterisktik respon keseluruhan pada operational amplifier. Fungsi utama dari rangakain operational amplifier adalah untuk melakukan operasi linier matematika (tegangan dan arus), integrasi dan penguatan. Terdapat macam macam rangkaian operational amplifier seperti komparator, inverting amplifier, non-inverting amplifier, summing amplifier, dan penguat differensial. Dalam penelitian rangkaian sesnsor ini digunakan rangkaian operational amplifier dengan jenis penguat differensial.

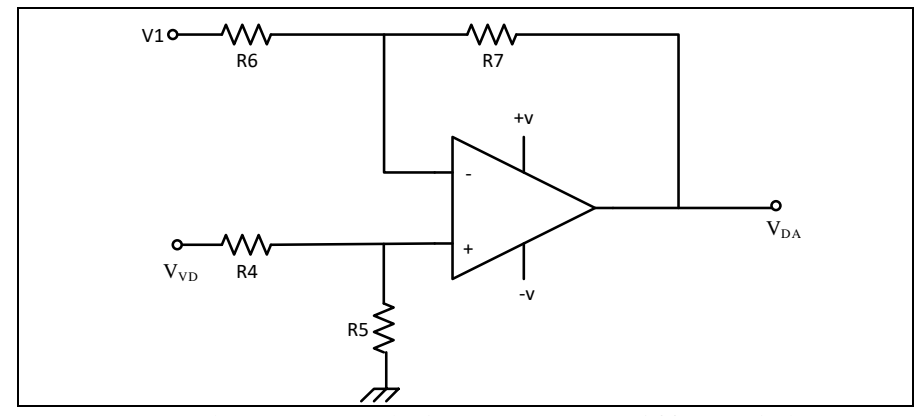

Gambar 5: Rangkaian Penguat Differensial Sumber: Penulis 2018 

dan Penguat Differensial pada Sensor Arus

Rangkaian penguat differensial merupakan rangkaian untuk mencari selisih antara dua titik tegangan yang berbeda. Rangkaian ini mampu menyinkirkan tegangan masukkan mode bersama (common mode) yang dinyatakan sebagai CMRR (Common Mode Rejection Ratio). Persamaan dari rangkaian penguat differensial ini dapat dinyatakan sebagai berikut.

$$
\begin{gathered}
V_{D A}=\left[\left(\frac{R 5}{R 4+R 5}\right)\left(\frac{R 6+R 7}{R 6}\right)\right] V_{V D} \\
-\left[\frac{R 7}{R 6}\right] V_{1} \\
V_{D A}=\left[\left(\frac{R 5}{R 4+R 5}\right)\left(\frac{R 4+R 5}{R 4}\right)\right] V_{V D}-\left[\frac{R 5}{R 4}\right] V_{1} \\
V_{D A}=\left[\frac{R 5}{R 4}\right] V_{V D}-\left[\frac{R 5}{R 4}\right] V_{1} \\
V_{D A}=\frac{R 5}{R 4}\left(V_{V D}-V_{1}\right)
\end{gathered}
$$

Dimana :

$V_{D A}$ merupakam tegangan keluaran dari rangkaian penguat differensial dasar,

$V_{1}$ merupakan tegangan refrensi,

$R_{4}=R_{6}$ merupakan tahanan masukkan,

$R_{5}=R_{7}$ adalah tahanan feedback.

\subsection{Pengukuran Arus dengan Metode Resistif}

Terdapat berbagai macam metode yang dapat digunakan untuk mengukur arus dalam suatu rangkaian listrik. Salah satu metode yang digunakan dalam mengukur arus rangkaian sensor arus pada penelitian ini adalah metode resistif.

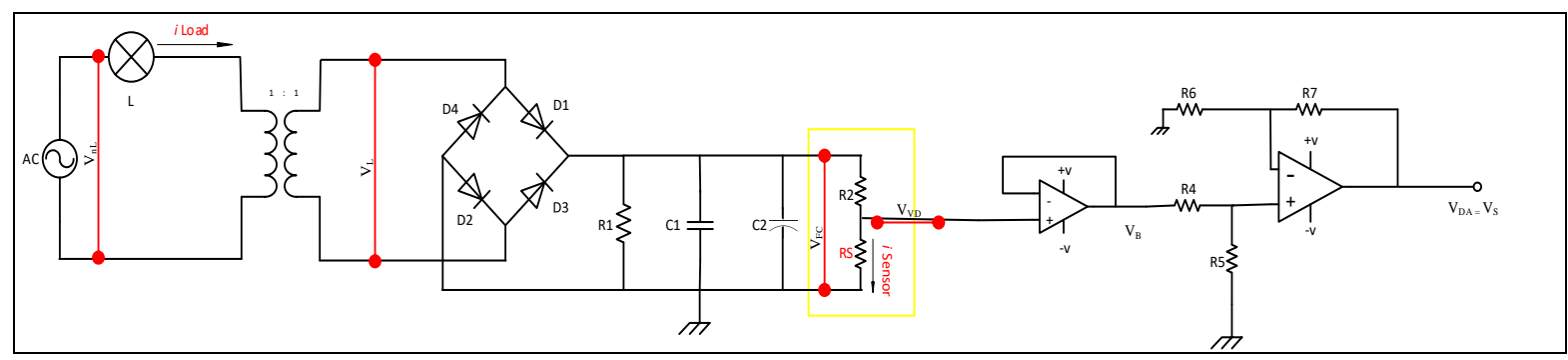

Gambar 6: Rangkaian Sensor Arus dengan Metode Pengukuran Resistif Sumber: Penulis 2018

Metode resistif adalah metode yang digunakan untuk mengukur arus dengan menetapkan salah satu tahanan pada jalur yang akan diukur sebagai tahanan referensi (Rs). Arus yang mengalir pada jalur tersebut akan dikonversi secara linier ke dalam satuan volt yang didasarkan pada hukum Ohm:

$$
\begin{gathered}
V_{F C}=I_{\text {Sensor }} \times R S \\
I_{\text {Sensor }}=\frac{V_{F C}}{R S}
\end{gathered}
$$

Dimana :

$V_{F C} \quad=$ tegangan keluaran dari rangkaian rangkaian penyearah gelombang penuh dengan filter kapasitor,

$I_{\text {Sensor }}=$ arus yang terukur pada sensor dan merepresentasi arus yang terukur pada beban $\left(I_{\text {Load }}\right)$,

$R S=$ tahanan referensi. 
Analisis Rangkaian Full Wave Rectifier dengan Filter Kapasitor, Pembagi Tegangan, Buffer dan Penguat Differensial pada Sensor Arus

\section{Hasil dan Diskusi}

Sensor arus yang dianalisis pada penelitian ini menggunakan dioda silicon (tegangan kerja $0,7 \mathrm{~V}$ ) jenis $1 \mathrm{~N} 4001$ dengan nilai $\mathrm{R} 1=1.2 \mathrm{~K} \Omega, \mathrm{C} 1=100 \mathrm{nF}, \mathrm{C} 2=100 \mu \mathrm{F}, \mathrm{R} 2=\mathrm{R} 3=1.2 \mathrm{~K} \Omega$, IC 324 sebagai buffer, $\mathrm{R} 4=\mathrm{R} 6=731,923 \Omega, \mathrm{R} 5=\mathrm{R} 7=500 \Omega$ dan IC741 sebagai penguat differensial. Pada simulasi dan perhitungan, digunakan tiga variasi beban (L) yaitu $100 \Omega, 200 \Omega$, dan $300 \Omega$ dan lima variasi tegangan tanpa beban $(\mathrm{VnL})$ yaitu $8 \mathrm{~V}, 12 \mathrm{~V}, 18 \mathrm{~V}, 23 \mathrm{~V}$, dan $27 \mathrm{~V}$. Dalam melakukan simulasi, digunakan software simulasi PSIM dan didapatkan data pada tabel 1.

Tabel 1: Hasil Simulasi dan Perhitungan Rangkaian Sensor Arus

\begin{tabular}{|c|c|c|c|c|c|c|c|c|c|}
\hline & $\begin{array}{l}\text { VnL } \\
\text { (VAC) }\end{array}$ & $\begin{array}{l}\mathbf{L} \\
(\mathbf{\Omega})\end{array}$ & $\begin{array}{c}\text { VL } \\
\text { (VAC) }\end{array}$ & $\begin{array}{c}\mathbf{V}_{\mathbf{F C}} \\
(\mathrm{VDC})\end{array}$ & $\begin{array}{c}\text { VVD }_{\text {VD }} \\
(\text { VDC) }\end{array}$ & $\begin{array}{c}\mathbf{V}_{\text {B }} \\
(\mathbf{V D C})\end{array}$ & $\begin{array}{c}\mathbf{V}_{D A}=V_{S} \\
(V D C)\end{array}$ & $\begin{array}{l}\text { ILOAD } \\
\text { (A) }\end{array}$ & $\begin{array}{l}\text { ISENSOR } \\
\text { (A) }\end{array}$ \\
\hline \multirow{14}{*}{ Simulasi } & \multirow{3}{*}{27} & 100 & 11,21 & 14,451 & 7,22578 & 7,22578 & 4,9302 & $8,026 \times 10^{-7}$ & 0,006215 \\
\hline & & 200 & 7,2 & 8,66 & 4,33031 & 4,33031 & 2,958 & $4,8 \times 10^{-7}$ & 0,0036086 \\
\hline & & 300 & 5,4 & 6,177 & 3,08886 & 3,08886 & 2,1104 & $3,43 \times 10^{-7}$ & 0,0025711 \\
\hline & \multirow{3}{*}{23} & 100 & 9,6 & 12,1993 & 6,09964 & 6,09964 & 4,1667 & $6,7747 \times 10^{-7}$ & 0,005083 \\
\hline & & 200 & 6,14 & 7,307 & 3,6534 & 3,6534 & 2,4957 & $4,0579 \times 10^{-7}$ & 0,0030446 \\
\hline & & 300 & 4,67 & 5,211 & 2,6054 & 2,6054 & 1,7798 & $2,89 \times 10^{-7}$ & 0,0021712 \\
\hline & \multirow{3}{*}{18} & 100 & 7,625 & 9,384 & 4,692 & 4,692 & 3,2053 & $5,2114 \times 10^{-7}$ & 0,0039102 \\
\hline & & 200 & 4,96 & 5,6153 & 2,8076 & 2,8076 & 1,9179 & $3,1184 \times 10^{-7}$ & 0,0023397 \\
\hline & & 300 & 3,82 & 4,0028 & 2,00143 & 2,00143 & 1,3672 & $2,2226 \times 10^{-7}$ & 0,0016679 \\
\hline & \multirow{3}{*}{12} & 100 & 5,238 & 6,0084 & 3,0042 & 3,0042 & 2,0522 & $3,336 \times 10^{-7}$ & 0,0025035 \\
\hline & & 200 & 3,527 & 3,5868 & 1,79341 & 1,79341 & 1,2251 & $1,9918 \times 10^{-7}$ & 0,0014945 \\
\hline & & 300 & 2,8 & 2,5543 & 1,27717 & 1,27717 & 0,87245 & $1,4182 \times 10^{-7}$ & 0,0010643 \\
\hline & \multirow{3}{*}{8} & 100 & 3,648 & 3,761 & 1,88045 & 1,88045 & 1,28456 & $2,0884 \times 10^{-7}$ & 0,001567 \\
\hline & & 200 & 2,572 & 2,237 & 1,11857 & 1,11857 & 0,76411 & $1,2423 \times 10^{-7}$ & 0,0009321 \\
\hline \multirow{16}{*}{$\begin{array}{l}\text { Perhitungan } \\
\text { (Teori) }\end{array}$} & & 300 & 2,114 & 1,590 & 0,7954 & 0,7954 & 0,54334 & $8,83 \times 10^{-8}$ & 0,0006628 \\
\hline & \multirow{3}{*}{27} & 100 & 11,21 & 14,453 & 7,2265 & 7,2265 & 4,936 & 0,38 & 0,0062 \\
\hline & & 200 & 7,2 & 8,782 & 4,39 & 4,39 & 2,99 & 0,135 & 0,003659 \\
\hline & & 300 & 5,4 & 6,23 & 3,11 & 3,11 & 2,13 & 0,09 & 0,00259 \\
\hline & \multirow{3}{*}{23} & 100 & 9,6 & 12,176 & 6,088 & 6,088 & 4,159 & 0,23 & 0,005073 \\
\hline & & 200 & 6,14 & 7,283 & 3,641 & 3,641 & 2,487 & 0,115 & 0,003036 \\
\hline & & 300 & 4,67 & 5,204 & 2,6021 & 2,6021 & 1,7776 & 0,0076 & 0,002168 \\
\hline & \multirow{3}{*}{18} & 100 & 7,625 & 9,3837 & 4,6916 & 4,6916 & 3,2050 & 0,18 & 0,003909 \\
\hline & & 200 & 4,96 & 5,614 & 2,807 & 2,807 & 1,9175 & 0,09 & 0,002339 \\
\hline & & 300 & 3,82 & 4,0023 & 2,00114 & 2,00114 & 1,367 & 0,06 & 0,001667 \\
\hline & \multirow{3}{*}{12} & 100 & 5,238 & 6,0076 & 3,0036 & 3,0036 & 2,052 & 0,12 & 0,0025031 \\
\hline & & 200 & 3,527 & 3,587 & 1,794 & 1,794 & 1,225 & 0,06 & 0,0014945 \\
\hline & & 300 & 2,8 & 2,559 & 1,279 & 1,279 & 0,874 & 0,04 & 0,001066 \\
\hline & \multirow{3}{*}{8} & 100 & 3,648 & 3,759 & 1,879 & 1,879 & 1,2839 & 0,08 & 0,001566 \\
\hline & & 200 & 2,572 & 2,237 & 1,1186 & 1,1186 & 0,764 & 0,04 & 0,000932 \\
\hline & & 300 & 2,114 & 1,589 & 0,7948 & 0,7948 & 0,5429 & 0,00267 & 0,000662 \\
\hline
\end{tabular}

Sumber : Penulis, 2018

Dari data tabel diatas, kami membandingkan pengaruh beban dan tegangan terhadap arus yang terukur pada sensor. Hasil perbandingkan disajikan dalam bentuk grafik seperti yang ditunjukkan pada gambar 7. Grafik menunjukkan bahwa semakin besar beban, maka arus akan semakin kecil. Berdasarkan perhitungan dan simulasi, hasil ini sesuai teori hukum Ohm dimana beban (tahanan) berbanding terbalik dengan arus dan berbanding lurus dengan tegangan.

Setelah dilakukan simulasi dan perhitungan secara teoritis, maka dibandingkan kedua hasil dan menghasilkan error seperti yang ditunjukkan pada tabel 2. Berdasarkan Tabel 2, nilai kesalahan simulasi terhadap perhitungan masih dalam batas toleransi dan berada pada rentang $0-0.99 \%$.

Selain melakukan perhitungan secara teori dan simulasi, kami juga melakukan percobaan secara langsung. Data percobaan secara langsung dijsajikan pada tabel 3. 
Analisis Rangkaian Full Wave Rectifier dengan Filter Kapasitor, Pembagi Tegangan, Buffer dan Penguat Differensial pada Sensor Arus

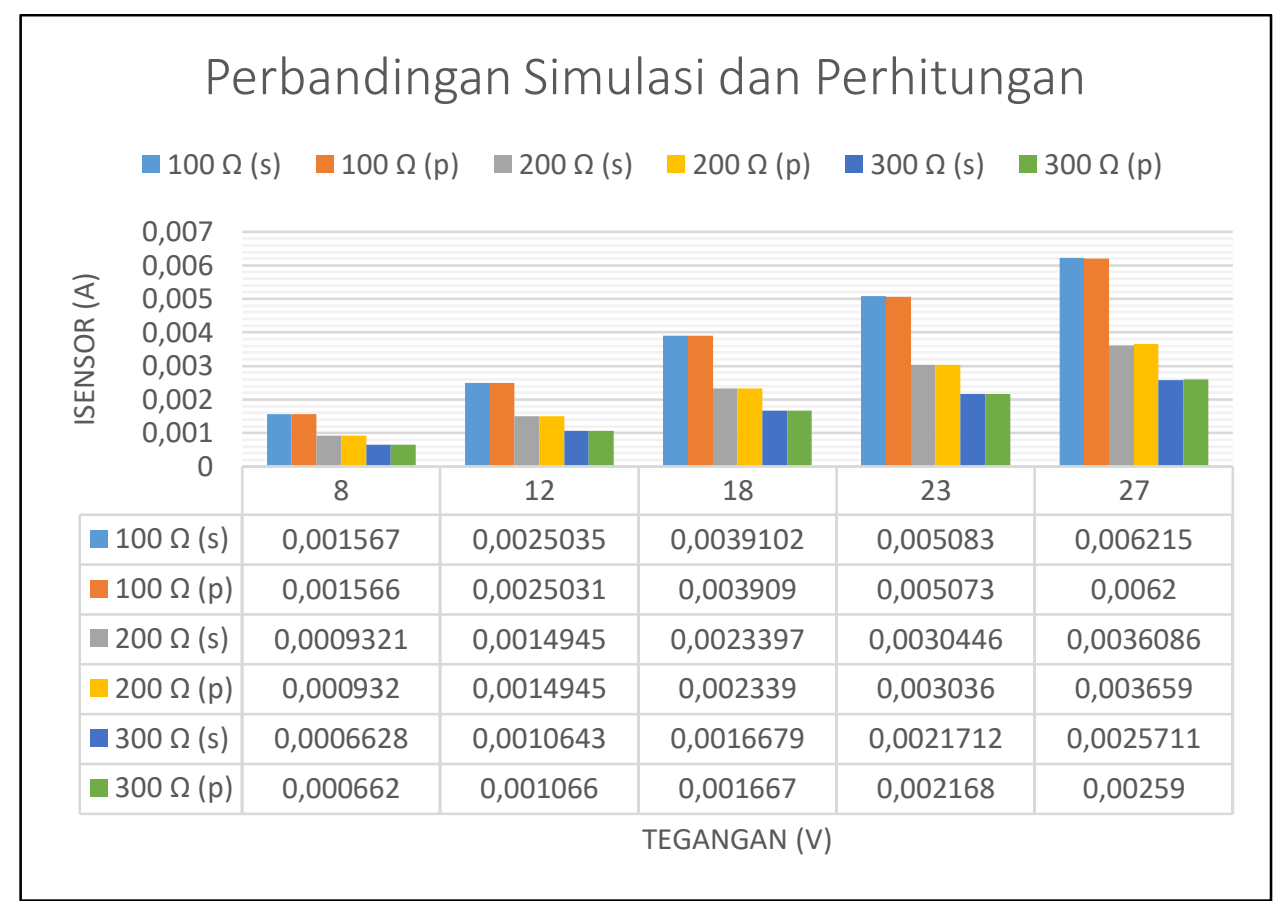

Gambar 7: Grafik Perbandingan Pengaruh Beban terhadap Arus dan Tegangan secara Simulasi dan Teori

Sumber: Penulis 2018

Tabel 2: Error Hasil Simulasi dan Perhitungan Rangkaian Sensor Arus

\begin{tabular}{|c|c|c|c|c|c|c|c|c|c|}
\hline & $\begin{array}{l}\text { VnL } \\
\text { (VAC) }\end{array}$ & $\begin{array}{c}\mathbf{L} \\
(\boldsymbol{\Omega})\end{array}$ & $\begin{array}{l}\text { VL } \\
(\%)\end{array}$ & $\mathrm{V}_{\mathrm{FC}}(\%)$ & $\mathrm{V}_{\mathrm{VD}}(\%)$ & $\mathrm{V}_{\mathbf{B}}(\%)$ & $\begin{array}{c}\mathbf{V}_{\mathrm{DA}}=\mathbf{V}_{\mathbf{S}} \\
(\%)\end{array}$ & $\begin{array}{c}\text { ILOAD } \\
(\%)\end{array}$ & ISENSOR (\%) \\
\hline \multirow{15}{*}{ Error } & \multirow{3}{*}{27} & 100 & 0 & 0,00014 & 0,0000996 & 0,0000996 & 0,00118 & 0,999997888 & 0,0024 \\
\hline & & 200 & 0 & 0,0139 & 0,013597 & 0,0136 & 0,0107 & 0,999996444 & 0,014 \\
\hline & & 300 & 0 & 0,00850 & 0,0068 & 0,0068 & 0,0092 & 0,999996189 & 0,007 \\
\hline & \multirow{3}{*}{23} & 100 & 0 & 0,0019 & 0,002 & 0,0019 & 0,001851 & 0,999997054 & 0,00197 \\
\hline & & 200 & 0 & 0,0033 & 0,0034 & 0,0034 & 0,003498 & 0,999996471 & 0,0028 \\
\hline & & 300 & 0 & 0,00134 & 0,00127 & 0,00127 & 0,001238 & 0,999961974 & 0,0015 \\
\hline & \multirow{3}{*}{18} & 100 & 0 & 0,000032 & 0,000085 & 0,0000852 & 0,0000936 & 0,999997105 & 0,00030 \\
\hline & & 200 & 0 & 0,00024 & 0,000214 & 0,00021 & 0,000209 & 0,999996535 & 0,0003 \\
\hline & & 300 & 0 & 0,00012 & 0,000145 & 0,000145 & 0,000146 & 0,999996296 & 0,00054 \\
\hline & \multirow{3}{*}{12} & 100 & 0 & 0,000133 & 0,0002 & 0,0002 & 0,0000975 & 0,99999722 & 0,00016 \\
\hline & & 200 & 0 & 0,000056 & 0,000328 & 0,00033 & 0,000082 & 0,99999668 & 0 \\
\hline & & 300 & 0 & 0,00183 & 0,00143 & 0,0014 & 0,0018 & 0,999996455 & 0,0016 \\
\hline & \multirow{3}{*}{8} & 100 & 0 & 0,00053 & 0,00077 & 0,00077 & 0,0005 & 0,99999739 & 0,00064 \\
\hline & & 200 & 0 & 0 & 0,0000268 & 0,000027 & 0,00014 & 0,999996894 & 0,00010 \\
\hline & & 300 & 0 & 0,00063 & 0,000755 & 0,000755 & 0,0008 & 0,999669288 & 0,00120 \\
\hline
\end{tabular}

Tabel 3: Hasil Percobaan Rangkaian Sensor Arus

\begin{tabular}{|c|c|c|c|c|c|c|c|}
\hline $\begin{array}{c}\text { VnL } \\
(\mathbf{V A C})\end{array}$ & $\begin{array}{c}\mathbf{L} \\
(\mathbf{\Omega})\end{array}$ & $\begin{array}{c}\mathbf{V L} \\
(\mathbf{V A C})\end{array}$ & $\begin{array}{c}\mathbf{V}_{\mathbf{F C}} \\
(\mathbf{V D C})\end{array}$ & $\begin{array}{c}\mathbf{V}_{\mathbf{V D}} \\
(\mathbf{V D C})\end{array}$ & $\begin{array}{c}\mathbf{V}_{\mathbf{D A}}=\mathbf{V}_{\mathbf{S}} \\
(\mathbf{V D C})\end{array}$ & $\begin{array}{c}\mathbf{I}_{\mathbf{L O A D}} \\
(\mathbf{A})\end{array}$ & $\begin{array}{c}\text { ISENSOR } \\
(\mathbf{m A})\end{array}$ \\
\hline \multirow{3}{*}{$\mathbf{9}$} & $\mathbf{8}$ & 2,7 & 4,99 & 2,779 & 2,927 & 0,054 & 1,99 \\
\cline { 2 - 8 } & $\mathbf{1 3}$ & 2,587 & 5,24 & 2,61 & 2,936 & 0,066 & 2,18 \\
\cline { 2 - 8 } & $\mathbf{1 8}$ & 2,222 & 4,85 & 2,348 & 2,9 & 0,093 & 2,32 \\
\hline \multirow{3}{*}{$\mathbf{1 8}$} & $\mathbf{8}$ & 4,3 & 12,18 & 5,87 & 2,933 & 0,054 & 4,39 \\
\cline { 2 - 8 } & $\mathbf{1 3}$ & 3,89 & 11,49 & 5,32 & 2,93 & 0,066 & 4,76 \\
\cline { 2 - 8 } & $\mathbf{1 8}$ & 3,61 & 10,87 & 5,25 & 2,925 & 0,093 & 4,98 \\
\hline \multirow{3}{*}{$\mathbf{2 7}$} & $\mathbf{8}$ & 7,59 & 18,53 & 8,98 & 2,934 & 0,054 & 6,94 \\
\cline { 2 - 8 } & $\mathbf{1 3}$ & 7,24 & 16,82 & 8,21 & 2,925 & 0,066 & 7,03 \\
\cline { 2 - 8 } & $\mathbf{1 8}$ & 6,42 & 16,67 & 7,98 & 2,923 & 0,093 & 7,72 \\
\hline
\end{tabular}



dan Penguat Differensial pada Sensor Arus

Perbedaan rangkaian percobaan secara langsung dengan teori dan simulasi adalah pada percobaan secra langsung kami tidak menggunakan rangkaian buffer, sehingga tegangan keluaran dari rangkaian pembagi tegangan tidak stabil dan menghasilkan nilai tegangan yang tidak sesuai dengan teori. Namun pada percobaan langsung terbukti bahwa semakin besar beban, maka akan semakin besar arus yang terdeteksi pada Isensor. Hal ini karena pengaruh beban pada simulasi maupun perhitungan akan berbeda pada realita lapangan.

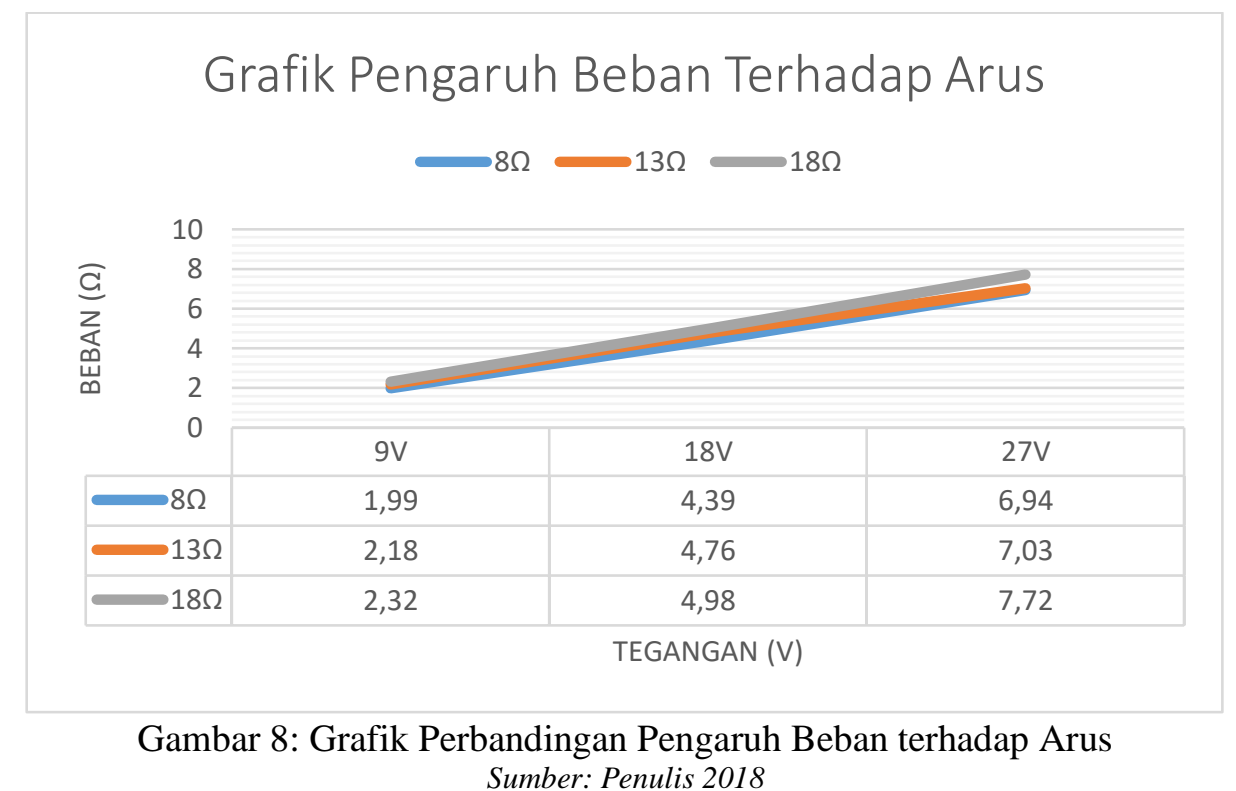

\section{Kesimpulan}

Telah dilakukan analisis teori dan percobaan mengenai rangkaian sensor arus yang terdiri dari rangkaian penyearah gelombang penuh dengan filter kapasitor, pembagi tegangan dan penguat diferensial. Metode pengukuran arus secara resistif yang diimplementasikan pada rangkaian ini telah dianalisis dan beberapa persamaan yang disajikan telah dibuktikan. Keuntungan rangkaian sensor arus jenis ini adalah murah, jangkauan pengukuran arus bervariasi dari rendah hingga medium, dan dapat mengukur arus AC ataupun DC. Kerugian rangkaian sensor arus jenis ini adalah rugi-rugi daya yang meningkat secara eksponensial disebabkan oleh disipasi daya, perubahan nilai arus yang terukur bergantung pada variasi beban yang diberikan dan sulit untuk mengaplikasikan sensor jenis ini pada rangkaian yang kompleks. Untuk penelitian kedepannya, diharapkan dapat menambahkan rangkaian buffer, menggunakan metode pengukuran arus yang lebih variatif pada rangkaian sensor ini dan pengukuran arus secara

\section{Ucapan Terima Kasih}

Penulis ingin berterima kasih kepada orang tua atas dorongan semangat, serta rekan-rekan di Teknik Elektro Institut Teknologi Kalimantan untuk dukungannya. Selain itu, penulis juga ingin berterima kasih untuk semua pihak dalam penyelesaian jurnal ini.

\section{Daftar Pustaka}

Adrian V. Crăciun, Sorin A. Moraru, Liviu Perniu, Dominic Mirrcea Kristaly, "Theoritical and experimental Analysis of the rectifier with capasitive filter,"eISSN-ResearchGate pp. 1-7, September 2005.

APP Note 746: High-Side Current-Sense Measurement: Circuits and Principles - MAX4080.

B. Bryant and M. Kazimierezuk, "Effect of a current-sensing resistor on required MOSFET size," IEEE Trans. On Circuit and System I: Fundamental Theory and Applications, vol. 50, pp. 708-711, May 2003. 
Analisis Rangkaian Full Wave Rectifier dengan Filter Kapasitor, Pembagi Tegangan, Buffer dan Penguat Differensial pada Sensor Arus

H. Forghani-zadeh and G. Rincon-Mora, "A lossless, accurate, self-calibrating current-sensing technique for DCDC converters, '32 nd Annual Conf. of IEEE Industrial Electronics. Society, 6-10 Nov. 2005.

H. Forghani-zadeh and G. Rincon-Mora, "Current-sensing techniques for DC-DC converters," $45^{\text {th }}$ Midwest Symposium on Circuits and Systems, vol. 2, Aug. 2002, pp.II-577- II-580.

H. Marecar and R. Oruganti, "Fast and Accurate Sensing in a Multiphase Buck Converter," IEEE International Conf. on Power Electronics. And Drives Systems, vol. 1, Jan. 2006, pp. 166-171.

J. Sun, J. Zhou, M. Xu, and F. Lee, “A Novel Input-Side Current Sensing Method to Achieve AVP for Future VRs,” IEEE Trans. On Power Electronics, vol. 21, pp. 1235-1242, Sept. 2006.

Microchip AN1332-Current Sensing Circuit Concept and Fundamentals.

“Current-Sensing solutions for power-supply designers,” Texas Instruments.

P. Givelin, M. Bafleur, E. Tournier, T. Laopoulus, and S. Siskos, “Application of a CMOS current mode approach to on-chip current sensing in smart power circuit." IEEE Proceedings-Circuit, Devices and System, vol. 142, pp.357-363, Dec 1995.

Zetex AN39-Current Measurement Applications Handbook. 